Abstracta Iranica Abstracta Iranica

Revue bibliographique pour le domaine irano-aryen

Volume 26 | 2005

Comptes rendus des publications de 2003

The Persian Contributions to the English Language. An Historical Dictionary. Wiesbaden, Harrassowitz Verlag, 2001, $190 \mathrm{p}$.

Pollet Samvelian

(2) OpenEdition

Journals

Édition électronique

URL : http://journals.openedition.org/abstractairanica/3617

DOI : 10.4000/abstractairanica.3617

ISSN : 1961-960X

Éditeur :

CNRS (UMR 7528 Mondes iraniens et indiens), Éditions de l'IFRI

Édition imprimée

Date de publication : 15 mai 2005

ISSN : 0240-8910

Référence électronique

Pollet Samvelian, «The Persian Contributions to the English Language. An Historical Dictionary. Wiesbaden, Harrassowitz Verlag, 2001, 190 p. », Abstracta Iranica [En ligne], Volume 26 | 2005, document 34, mis en ligne le 15 décembre 2005, consulté le 25 septembre 2020. URL : http:// journals.openedition.org/abstractairanica/3617; DOI : https://doi.org/10.4000/abstractairanica.3617

Ce document a été généré automatiquement le 25 septembre 2020.

Tous droits réservés 


\title{
The Persian Contributions to the English Language. An Historical Dictionary. Wiesbaden, Harrassowitz Verlag, 2001, 190 p.
}

\author{
Pollet Samvelian
}

Ce dictionnaire de 811 entrées signale les mots empruntés par l'anglais au persan, soit de façon directe, soit par l'intermédiaire des langues telles que l'arabe, le turc, l'urdu ou l'hindi, ce deuxième groupe formant de loin la majorité des mots recensés. Les entrées ont été répertoriées à partir des sources écrites, constituées pour l'essentiel de dictionnaires monolingues de l'anglais, tels Oxford English Dictionary, Webster's Unabridged Dictionary, Third Barnhart Dictionary, American Heritage et Universal Dictionary. Chaque entrée comporte la date de la première attestation connue pour le mot en anglais à l'écrit, son champ sémantique ( 35 champs, au total), ses variantes phonétiques ou orthographiques, son étymologie, ses diverses acceptions dans un ordre chronologique, ainsi que les différentes formes dérivées ou composées qui lui sont reliées.

\section{INDEX}

Thèmes : 2.2. Langues vivantes et dialectes

Mots-clés : linguistique, Dictionnaire, Dictionnaire historique, phonétique, étymologie, linguistique persan

Keywords : linguistics, Dictionary, Historical Dictionary, phonetics, etymology, Persian linguistics 


\section{AUTEURS}

\section{POLLET SAMVELIAN}

Sorbonne Nouvelle - Paris III 